\title{
An Analysis of Culture-specific Items in the Persian Translation of "Dubliners" Based on Newmark's Model
}

\author{
Seyed Mohammad Hosseini Maasoum \\ Department of Linguistics \& Foreign Languages, Payame Noor University, 19395-4697 Tehran, Iran \\ Email: hosseinimasum@pnu.ac.ir \\ Hoda Davtalab \\ Islamic Azad University, Quchan Branch, Iran \\ Email: hoda.davtalab@gmail.com
}

\begin{abstract}
Different cultures influence the way the members of a society view and perceive the world. This principle is important in the translation phenomenon. What is important for a translator is the purpose of conveying the message of the source text in a way understandable for the audience in the target text (TT). Therefore, every translator should have some knowledge about how to deal with different strategies of translating culture specific item (CSI); hence this issue is one of the most important concerns for all translators. In translation CSI refers to those concepts and references of the vocabulary items which are peculiar to the given culture. Sometimes these concepts and references are common to all languages, but they are expressed in a way peculiar to the culture of the source text (ST). Using an appropriate and suitable method in dealing with CSIs is one of the main duties of every translator. In this paper an attempt has been made to show how the translation of Dubliners jointly by Safaryan and Salehhosseini handle the translation of CSIs in this story based on Newmark's model (1988). Newmark described fourteen methods for translating CSIs: transference, naturalization, cultural equivalent, functional equivalent, descriptive equivalent, componential analysis, synonymy, through-translation, shift, modulation, accepted standard translation, compensation, paraphrase, couplet and finally notes. Although there are different ways and methods for translating CSIs, we show here that the translator sometimes cannot find a completely corresponding equivalent for them in the TT. This is somehow related to Jackobson's $(1959 / 2000$, p.114) idea that in translation "there is ordinarily no full equivalence between code- units".
\end{abstract}

Index Terms - translation, culture-specific items, Newmark, literary translation, equivalence, Dubliners

\section{INTRODUCTION}

Many translation theorists have tried to define culture. Newmark sees culture as "the way of life and its manifestation to uses a particular language as its means of expression" (1998, p. 94). Finding the best equivalent for culture specific items (CSIs) in translation is one of the main concerns for each translator. Translation as defined by Miremadi (1993, p.23) is a reciprocal process from one culture to the other and from other cultures into one culture. In other words, there is a "give- and-take process". In this process, translators deal with some non-equivalent words for which they should find an appropriate equivalent.

The translators need to find an equivalent with the same concept in the target text (TT). In cases where concepts are not identical, they cannot be used interchangeably in even two dialects of the same language. There are many words in each language for which there is no "full equivalent" (Jakobson, 1959/2000, p.114) in the TT. One of the most difficult problems a translator face is how to find lexical equivalents for the areas and aspects which are not known in the receptor culture i.e. there is not a corresponding word or phrase in the receptor language easily available for the translation. A translator has to consider not only the two languages but also the two cultures, since there will be some concepts in the source language, which do not have lexical equivalents in the target language. This may be due to difference of geography, customs, beliefs, worldview, and various other factors (Larson, 1998, p.163). Even if close equivalents are found, they can rarely reveal and convey exactly the same massages.

Sometimes, there are some words or phrases in one language which are unknown for another language. This phenomenon is called "semantic void or lexical gap" (Gambier et.al, 2004, p.11). In some cultures lexical gap may be observed in a way that people make distinctions between different aspects of a concept. For instance, the Arabs use 20 different words to identify different kinds of camels and they "conceptualize camels more specifically...in their cultural groups" (Stemberg et.al, 2009, p.388). However people in other countries like Iran do not make any distinctions between different kinds of camels; they use a generic word for all these different aspects. In their hypothesis of linguistic relativity, Edward Sapir and Benjamin Whorf also hold that the language we speak both affects and reflects 
our view of the world (cited in Armstrong, 2005, p.16). In a popular 1940 article, Whorf referred to Eskimo languages having seven distinct words for snow. In some communities, this concept may not have been lexicalized. For example in some parts of the world the inhabitants have not seen snow, hence they don't have any word to carry the concept.

It is obvious that each community has its own CSIs peculiar to its language. Each word or expression may refer to a concept which is different from one language to another. For example, pig or owl may have the same denotative and dictionary meaning in different languages, but they may convey totally different and even opposite senses in two different languages depending on the culture of the society. It is necessary for a professional translator and even the students of translation to be aware of cultural differences. Translators should be able to find a range of possibilities that include all the diversities of translation strategies which can be used to solve the problems of translating CSIs between languages.

This research intends to identify some strategies for finding the meaning of culture specific items which are applied by different translators in different literary texts. The debates of this paper are illustrated by the use of some examples of the book Dubliners by James Joyce (1914) and its Persian translation jointly by Mohammad Ali Safaryan and Saleh hosseini (1993). The current study tries to investigate whether the translators have been successful in conveying the embedded culture specific items of the original text or not. Newmark's (1988) classification of CSIs has been adopted as the theoretical framework of this study.

\section{CSIS IN TRANSLATION}

Cultural aspects are of paramount importance in translation studies. This issue attracts the attention of many scholars in a way that we can say cultural debates are one of the central issues in "translatology". Talking about the translation of CSIs is also controversial, since a single identical word or phrase may be translated in different ways by different translators. However, what is important is the solution of a translator facing CSIs in the text for finding their appropriate meaning and a suitable equivalent for these items in the TT. Consequently it is important for translators to be familiar with different methods and strategies in dealing with CSIs.

\section{A. Conveying Form and Meaning in the Translation of CSIs}

There are different methods adopted by translators for translating CSIs. Some people may believe that we can't translate CSIs, since they are related to a specific culture. But Baker (1992, p.68) believes that "idioms and fixed expressions which contain culture-specific items are not necessarily understandable. It is not the specific items an expression contains but rather the meaning it conveys and its association with culture-specific context which can make it understandable or difficult to translate."

Based on this statement, the translation of CSI is not impossible, but rather complicated for the translator. Although the translator should try to convey both form and meaning, their goal is "to keep the meaning constant" and sometimes "the receptor language form should be changed in order that the source language meaning not be distorted" (Larson, 1998, p.12). In addition, Nida (1964) mentioned that whenever there is a "conflict" between form and content "correspondence in meaning must have priority over correspondence in style" (cited in Munday, 2001. p.42). Hence in the translation of CSIs the translator tries to focus on conveying the meaning, not the form. In other words, in the translation of these instances the priority is the meaning. We can consider idioms as a subdivision of CSIs because they reflect aspects of the life of the TL speakers. For example, when the translator wants to translate "to carry coals to Newcastle" to Persian by conveying the form of the original, the meaning will be lost. In Persian the meaning of this equivalent is expressed in the following proverb:

$$
\text { زيره به كرمان بردن }
$$

/zIrə bə kərman bordan/

To take caraway to Kerman.

A Persian native speaker knows that زيره (caraway) is something that we can find large quantities in Kerman. Therefore, it is the translator's duty to keep the meaning of the original sometimes at the cost of SL form.

\section{B. The Translation of CSIs in the Context of Globalization}

Globalization describes a social trend that intensifies relations between societies and nations, a process by which decisions, events and activities from one part of the world have strong influences on other distant parts of the world (Sandrini, 2006, p.110). It plays an important role in different aspects of our life such as economy, politics, language, translation, etc. However, in the globalized world, translation studies and more specifically translation of CSIs become more important. Globalization makes people interested in familiarity with other cultures in different aspects. Translation and globalization, therefore, are interrelated.

Wiersema (2004) believes that globalization is important in translation, because it makes different cultures closer to each other. He expresses that "context explains culture, and adopting (not necessarily adapting) a selection of words enriches the target text, makes it more exotic and thus more interesting for those who want to learn more about the culture in question". As a result each text is produced in the context of a certain culture and has its specific values, behaviors and norms and is expressed by CSIs in that culture. In some cases these CSIs are global. It means that they 
may have the same sense and concept in many different languages which are expressed by different forms. Therefore there is no problem in translating of the text. The problem is when the concept has been globalized.

\section{Language and Culture}

It is obvious that language and culture are closely intervowen. Human beings can express different aspects of their culture by using language. Therefore, language can influence the way of our thinking. Sapir acknowledges the close relationship between language and culture, he believes that these two aspects are inextricably related; consequently, we cannot understand or appreciate the one, without knowledge of another (1929, p.207). He describes that "No two languages are ever sufficiently similar to be considered as representing the same social reality" (ibid, p. 69).

In Whorf's view, language provides a screen or filter to reality; it determines how speakers perceive and organize the world. Consequently, the language that we speak helps us to shape our world view. It defines our experience (cited in Wardhaugh, 2010, p.233). Language is, therefore, not just a means for communication, but rather an influential factor in our way of thinking. Considering Sapir and Whorf's hypothesis, we can conclude that the person's environment and culture affect his understanding of the message.

Snell-Hornby (1988, p.35) stated that "both the translator and the translation theorists are... concerned with a world between disciplines, language and culture". She adds that the relationship between language and culture was first formally formulated by Wilhelm Von Humboldt who knows language as something dynamic and also as an expression of culture of the speakers, who understand and perceive the world through language (ibid. p.40).

\section{Problems in Translating CSIs}

The world that we live in, is full of different languages; these languages live in the context of different cultures manifesting different aspects of life. As far as the relation among these languages is concerned, translation becomes an indispensible necessity. Translators face many problems in translating CSIs, and translation scholars suggest some methods to solve them.

In translation of CSIs the translator may confront some problems. As Leppihalme (1997, p.2) reports, some researchers consider "extralinguistic phenomena from natural to man made. Extralinguistic problems are often expressed as lexical... Others see culture bound translation problems a mainly intralinguistic and pragmatic". He adds "Culturally oriented translation studies do not see the ST and TT as samples of linguistic material. The texts occur in a given situation in a given culture in the world and each has a specific function and an audience of its own" (ibid, p.3).

People belonging to the same linguistic community are members of a certain type of culture. They possess shared traditions, habits, behavior, and common knowledge about their society and many other aspects. Consequently, in interlingual communication where two or more cultures exist, the translator may face some limitations which impede the process of understanding the TT by the reader. The translator has not only the problem of linguistic obstacles but also the problem of cultural barriers (Komissarov,1991, pp.33-4). What is necessary for translators is that they should find an appropriate method in dealing with CSIs based on the text and the situation. Lacking some concepts in one of the two languages in translation process is problematic for the translator. There are some concepts in one language that are completely absent in another language. For example in Persian we have some new words which are common often among young people, like خفن /xafan/ (The perfect and best way or thing) or ضايع /zaye?/ (Very bad thing and situation; used for animate and inanimate things).

On the other hand sometimes it is possible that the TT and ST reader have totally different understanding of a single concept in two different languages. For example, some religious words like نماز ، جهاد، حج، زكات، كافر may have a nearsynonym equivalent in the TT, but they cannot render the same concepts as the original. Obviously understanding these words by a reader of the ST is different from the understanding of the TT readers. Different categorizations of the concepts in languages are also problematic in the translation process. Among these concepts, divergence and convergence are two main points that should be noticed by a translator (Fawssett, 1997, p.43). Divergence occurs when a single item in the ST splits to two or more items in the TT. For example, the verb ديدن/dIdan/ in Persian can diverges into English see, watch, look at. In contrast, when two or more items in the ST merge into just one item in the TT, it is

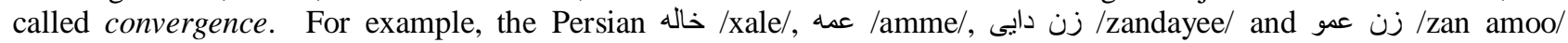
(differentiate by their relationship to father or mother) converge into English aunt. However in English there is no such a distinction.

\section{Strategies in Translating CSIS FROM DifFERENT PoinT OF VIEWS}

Different scholars have analyzed the strategies and procedures involved in the translation of CSIs, suggesting various classifications of such strategies. One of the pioneers in this field was Newmark (1988). He suggests a number of procedures for translating CSIs, namely transference, naturalization, cultural equivalence, functional equivalence, descriptive equivalence, synonymy, through-translation, shift or transposition, modulation, recognized translation, translation label, compensation, componential analysis, reduction and expansion, paraphrase, couplet, and notes (1988, pp.81-93).

In more recent studies some other classifications have been suggested for such strategies. Graedler (2000, p.3) observes translators applying such methods as: making up a new word, selecting a word in the TL which seems similar 
to or has the same "relevance" as the SL term, preserving the SL term intact, explaining the meaning of the SL expression instead of translating it.

Pederson (2005, p.3) employed the word "rendering" instead of "translating" and also the term Extralinguistic Culture-bound Reference (ECR) instead of Culture Specific Item (CSI).According to Pedersen, culture-bound terms may be intralinguistic and extralinguistic culture-bound references. Based on Pederson's statement, strategies for rendering extralinguistic CSIs are SL oriented and TL oriented.

Source language oriented strategy consists of three subcategories: (Pederson, 2005, pp.3-9)

a. Retention. This strategy is SL oriented, since an item from the SL can enter the TT. In some cases the culturebound term is distinguished from other parts by the employment of some symbols like quotation marks and italics.

b. Specification. It means that the translator doesn't translate CSI and leaves it in "its untranslated form", but s/he adds some extra information in the TT that doesn't exist in ST, thus making the target CSI more specific than the CSI of the ST. This is done through Explicitation or Addition.

b.1. Explicitation. "Explicitation could be seen as any strategy involving the expansion of the text, or spelling out anything that is implicit in the source text."

b.2. Addition. It means that the added material is not obvious in the CSI of the ST," as part of the sense or connotations of the term".

c. Direct translation. In this strategy "the semantic load", of CSI of the ST doesn't change and "nothing is added, or subtracted." This strategy has two subgroups: calque which is the result of literal translation, and shifted direct translation which refers to those terms that are common in target culture and are "less SL oriented".

Pederson suggests three subcategories for target language oriented strategies:

a. Generalization. This involves replacing a CSI "referring to something specific by something more general. Typically, this involves hyponymy".

b. Substitution. It is the removal of CSIs of the SL and "replacing them with something else, either a different term or some sort of paraphrase, which does not necessarily involve" a cultural term. This strategy consists of two subgroups: cultural substitution and paraphrase.

b.1. Cultural substitution. It means that the CSI of the ST is removed, and replaced by a different CSI. These CSIs which are used in TT are completely known by the audience.

b.2. Paraphrase. "This strategy involves rephrasing the source culture-specific item, either through reduction to sense, or by completely removing all trace of the cultural term and instead using a paraphrase that fits the context".

c. Omission. It means "replacing the ST with nothing." Of course, what is obvious is that this strategy should be the last choice of the translator if we believe that a good translator should be faithful to the original text.

We can see many of these strategies described by different scholars are the same and they describe identical phenomena, but they are called by different names.

Hervey and Higgins (2006) mentioned that it is better for a translator to use cultural translation instead of literal translation. They believe that cultural transposition has a scale of degrees. This scale is from a degree which is based on source culture (exoticism) and moves toward the degree which is mostly based on target culture (cultural transplantation). It includes: (cited in Mizani, 2003) ${ }^{1}$.

a. Exoticism: "The degree of adaptation is very low here. The translation carries the cultural features and grammar of SL to TL. It is very close to transference"

b. Calque: "Calque includes TL words but in SL structure therefore while it is unidiomatic to target reader but it is familiar to a large extent".

c. Cultural Borrowing: "It is to transfer the ST expression verbatim into the TT. No adaptation of SL expression into TL forms. After a time they usually become a standard in TL terms. Cultural borrowing is very frequent in history, legal, social, political texts; for example, "La langue" and "La parole" in linguistics".

d. Communicative Translation: "Communicative translation is usually adopted for culture specific clichés such as idioms, proverbs, fixed expression, etc. In such cases the translator substitutes SL word with an existing concept in target culture. In cultural substitution the propositional meaning is not the same but it has similar impact on target reader. The literal translation here may sound comic. The degree of using this strategy sometimes depends on the license which is given to the translator by commissioners and also the purpose of translation".

e. Cultural Transplantation "The whole text is rewritten in target culture. The TL word is not a literal equivalent but has similar cultural connotations to some extent. It is another type of extreme but toward target culture and the whole concept is transplanted in TL. A normal translation should avoid both exoticism and cultural transplantation".

\section{PROCEDURE}

This study is a descriptive and library research and its aim is to carry out an analysis and description of strategies applied by different translators to cope with CSIs and to find whether these strategies are universal or idiosyncratic. Therefore, the translation of a literary text was compared with the original text and each strategy was illustrated by examples for better understanding.

\footnotetext{
${ }^{1}$. http://www.translationdirectory.com/articles/article1507.php
} 
After studying the classifications of cultural categories by translation scholars, a general view about these categories was acquired and then during the comparison of the source and the target text the culture bound terms or CSIs were extracted. The theoretical framework of this research is based on what Newmark (1988) expressed in his book " $A$ Textbook of Translation" about the translation of CSIs.

The English sentences in which the CSIs occurred and their translation were extracted from Dubliners by James Joyce (1914) and its Persian translation دوبلينى ها /dublInIha/ which is translated by Salehhosseini and Mohammad Ali Safaryan (1993). For a few number of strategies, we found no examples. In these cases, an attempt has been made to use some other Persian translations just for the sake of exemplification.

The next process was searching for the exact meaning of the terms in the Webster and Oxford dictionaries. Having identified CSIs of the literary text, we went on to the last step which was selecting different semantic voids from different domains.

\section{A. Newmark's Model}

There are some strategies which translator can use to fill the lexical gaps in the translation of culture specific items. These strategies are described by many translation scholars. For Newmark $(1988$, p.82) the term cultural equivalent means "an approximate translation where a SL cultural word is translated by a TL cultural word". In this part, strategies described by Newmark (mentioned in part 3), will be explained and illustrated in detail through some Persian sentences extracted from the translation of Dubliners for better understanding.

In 1964, Nida took up the problems of correspondence and translation of some items which are different culturally in SL and TL. He concluded that the differences between the cultures will cause the translator to face many problems and complications. He also explained that the parallels in culture often provide a common understanding despite significant formal shifts in translation. Newmark used this point of view and described his five "cultural categories" and their subcategories that culture specific items may come from (1988, pp.94-103).

He proposed a classification for classifying foreign cultural words. These five categories are:

1) Ecology (flora, fauna, winds, plains, hills)

2) Material culture (food, clothes, houses and towns, transport)

3) Social culture (work and leisure)

4) Organizations, customs, activities, procedures, concepts (political and administrative, religious, artistic)

5) Gesture and habits

In what follows, some strategies are described accompanied by their example (s) for finding an appropriate equivalence for CSIs which are described by Newmark (In some cases it is also expressed by some other translation scholars by different names). We, then, identify the class into which each example falls.

\section{a. Transference}

According to Newmark (1988, p.81) "Tranference is the process of transferring a SL word to a TL text as a translation procedure". He believes that only cultural objects or concepts related to a small group should be transferred (ibid). When the translators face the following cases, they should use the method of transference: name of all living or dead people, geographical names, name of the periodical and newspapers, titles of untranslated literary works, plays, films; names of private companies and institutions, names of public institutions; street names and addresses (ibid, p.82). As Kalèdaitè (2005, p.32) puts in his article, Newmark's transference (1988, p.81), Harvey and Higgins' cultural borrowing (1992, p.31), Baker's Loan words (1992, p.34), Chesterman's exoticizing (1997) and finally Schaffner and Wiesemann's naturalization (2001) are identical. Newmark believes that the translator uses this method to "attract the reader or to give a sense of intimacy between the text and the reader" (Newmark, 1988, p.82).

\begin{tabular}{|c|c|c|c|}
\hline Number & ST & literal meaning & TT \\
\hline 1 & $\begin{array}{l}\text { The Rev. James Flynn, aged } \\
\text { sixty- five years. }\end{array}$ & $\begin{array}{l}\text { James Flynn died in sixty-five } \\
\text { years. }\end{array}$ & 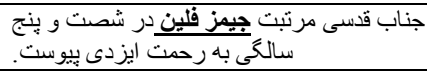 \\
\hline
\end{tabular}

James Flynn is the name of "living people", so the translator transferred (transliterated) it.

\begin{tabular}{|c|c|c|c|}
\hline Number & ST & literal meaning & TT \\
\hline 2 & $\begin{array}{l}\text { He had a little library made up } \\
\text { of old numbers of The union } \\
\text { Jack, Pluck and The } \\
\text { Halfpenny Marvel. }\end{array}$ & $\begin{array}{l}\text { He had a little library full of old } \\
\text { version of some magazines of } \\
\text { The union Jack, Pluck and The } \\
\text { Halfpenny Marvel. }\end{array}$ & 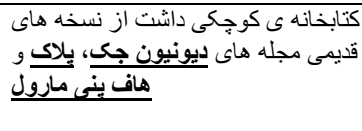 \\
\hline
\end{tabular}

In this sentence we have the name of some "untranslated literary texts" so they should be transferred to the TT. This example falls into Newmark's third kind of categorization (social culture).

\begin{tabular}{|c|c|c|c|}
\hline Number & ST & literal meaning & TT \\
\hline 3 & $\begin{array}{l}\text { Near it on plate lay a very light } \\
\text { plum-pudding. }\end{array}$ & $\begin{array}{l}\text { Beside it, on the plate, there } \\
\text { was a piece of very soft plum }\end{array}$ & كنار آن در بشقاب تكه اى بودينگ آلوى \\
\hline
\end{tabular}

Pudding is a sweet and usually hot dish made with pastry, flour, bread or rice, and often fruit. In this sentence the translator has used the word itself in the Persian sentence and pudding is transferred into TL. 
It falls into Newmark's second categorization, material culture because pudding is the name of a food which is one of the sub-categories of material culture.

\section{b. Naturalization}

"This procedure succeeds transference and adapts the SL word first to the normal pronunciation, then to the normal morphology of the TL" (ibid, p.82).

\begin{tabular}{|c|c|c|c|}
\hline Number & ST & literal meaning & TT \\
\hline 4 & $\begin{array}{l}\text {..like the word gnomon in the } \\
\text { Eucilid and the word simony in } \\
\text { the Catechism. }\end{array}$ & 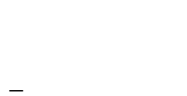 & 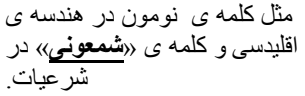 \\
\hline
\end{tabular}

This example falls to Newmark's forth categorization; since we deal with religious terms.

\section{c. Cultural Equivalent}

This strategy is "an approximate translation where a SL cultural word is translated by a TL cultural word" (Newmark, 1988, p.83). However, "they are not accurate".

\begin{tabular}{|c|c|c|c|}
\hline Number & ST & literal meaning & TT \\
\hline 5 & $\begin{array}{l}\text { A companion dish on which lay } \\
\text { a solid rectangle of Smyrna } \\
\text { figs, a dish of custard topped } \\
\text { with grated nutmeg. }\end{array}$ & $\begin{array}{l}\text { There was a plate of custard } \\
\text { which was covered by a solid } \\
\text { rectangle of Smyrna figs. }\end{array}$ & يكى ظرف فرنس با رويه آى از جوز \\
\hline
\end{tabular}

Custard is a pudding-like usually sweetened mixture made with eggs and milk. In Persian, the most natural equivalent for this word is فرنسى/fərnI/, however it cannot have the same connotative meaning. Materials which are used for making فرنى do not include egg and it has a combination of some other materials. So according to Newmark's statement explained above, the word فرنى in Persian is not an "accurate" equivalent for the English word.

is one of the sub-categories of Newmark's second general categorization which is material culture, since it is kind of food.

\section{d. Functional equivalent}

According to Newmark, functional equivalent "applied to cultural words, requires the use of a culture-free word, sometimes with a new specific term; it therefore neutralizes or generalizes the SL word". He also defines functional equivalent as "The most accurate way of translating i.e. deculturalizing a cultural word" (1988, p.83).

\begin{tabular}{|c|c|c|c|}
\hline Number & ST & literal meaning & TT \\
\hline 6 & They drink for luck. & They drank a glass. & براى برخوردار شدن از بخت كيلاسيى. \\
\hline
\end{tabular}

In this sentence drink is a verb. Here it has been changed to a noun. In the Persian text, Drink is alcoholic liquid and it is a noun. So it is a general word, but in the translation sentence it is used more specific.

Again we deal with Newmark's second categorization (material culture and its sub-categorization that in this sentence is food).

\begin{tabular}{|l|l|l|l|}
\hline Number & ST & literal meaning & TT \\
\hline 7 & $\begin{array}{l}\text { Ignatius Gallaher made a } \\
\text { catholic gesture whit his right }\end{array}$ & $\begin{array}{l}\text { Ignatius Gallaher made a Cross } \\
\text { gesture by his right hand. }\end{array}$ & $\begin{array}{l}\text { (يكناتيوس كالا هر با دست راست كثيد } \\
\text { arm. }\end{array}$ \\
\hline
\end{tabular}

Catholic gesture is kind of gesture which is familiar to SL readers, but the readers in Persian can understand it by the use of صليب (cross).So the translator has narrowed the meaning of the word.

This sentence falls in Newmark's fifth category which is gesture and habit.

\section{e. Descriptive equivalent}

"Description and function are essential elements in explanation and therefore in translation" (Newmark, 1988, p.84). Using this strategy enable us to have a correct perception of CSIs by using other words and phrases. In this strategy the translator uses some descriptions to clarify the meaning for his audience. Nida (1964, p.237) mentioned "descriptive equivalents are deliberate attempts to produce satisfactory equivalents for objects, events, attributes and relationals for which no regular term exists in the receptor language". He also mentioned that the most common types of descriptive equivalents are objects and attributes (ibid).

\begin{tabular}{|c|c|c|c|}
\hline Number & ST & literal meaning & TT \\
\hline 8 & $\begin{array}{l}\text { Joe had gone to Belfast on a } \\
\text { White-Monday trip. }\end{array}$ & $\begin{array}{l}\text { Joe had gone to Belfast for the } \\
\text { Holy Spirit. }\end{array}$ & روح در سفرى بله بلفاست رناسبت دوشنبه نزود. \\
\hline
\end{tabular}


In this example the translator explains the underlined phrase for his audience in the TT. It is observable that the translator uses some words to describe the clear meaning for the reader of the TT. This sentence falls in to Newmark's fourth categorization (Organizations, customs, activities, procedures, concepts), since it is related to religious terms.

\begin{tabular}{|c|c|c|c|}
\hline Number & ST & literal meaning & TT \\
\hline 9 & $\begin{array}{l}\text { He revealed many of the secrets } \\
\text { of religious houses on the } \\
\text { continent. }\end{array}$ & $\begin{array}{l}\text { He revealed a lot of the secrets } \\
\text { of European religious houses. }\end{array}$ & بسبارى از اسر ار اماكن مذهبي ارويًا را. \\
\hline
\end{tabular}

In this sentence religious house is translated to ماكن مذهبى ارويا (religious places in Europe). The translator has used several words to transfer the exact meaning. Here we deal with Newmark's forth type of categorization which is Organizations, customs, activities, procedures, concepts since religion in this sentence is one of the sub-categories of the forth type. At the same time we have the word house in the sentence which is one of the sub-categories of material culture (Newmark's second category).

\section{f. Componential analysis}

As Larson (1998, p.59) has mentioned "a word is a "bundle" of meaning component. The translator needs to be able to analyze the lexical items of the source text in order to translate them. This means being able to "unpack" words in order for the meaning to be represented by the lexical form."

Componential analysis is defined as "comparing an SL word with a TL word which has a similar meaning but is not an obvious one-to-one equivalent, by demonstrating first their common and then their differing sense components. Normally the SL word has more specific meaning than the TL word" (Newmark, 1988, p.114).

\begin{tabular}{|c|c|c|c|}
\hline Number & ST & literal meaning & $\mathrm{TT}$ \\
\hline 10 & $\begin{array}{l}\text { He knew that people went there } \\
\text { after the theatre to eat oysters } \\
\text { and drink liqueurs. }\end{array}$ & & 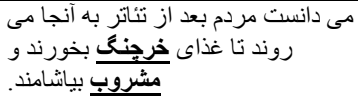 \\
\hline
\end{tabular}

Oxford advanced leaner's dictionary defines Oyster as a large flat sea creature that lives in a shell, some types of which can be eaten either raw or cooked. The translator has used the word خرجنَ (crab) as the equivalent for it. Comparing SL and TL, it is obvious that both of these two words are sea food, but "there is no one to one correspondence" between them.

Liqueur is also a strong, sweet alcoholic drink which is usually drunk in small amounts at the end of a meal. The word مشروب (alcoholic drink) in Persian doesn't transfer such a meaning; so again we can say there is no one to one correspondence between liqueur in English and ششروب (alcoholic drink) in Persian.

What is obvious is that in translating oyster and liqueur, the translator deals with Newmark's second general categorization (material culture), since both of them are food. It is noticeable that the word oyster in TL belongs to Newmark's second categorization (material culture), however when it is translated into Persian خرجنَ (crab) in falls into the first categorization (ecology, of which one sub-categorization is fauna).

\section{g. Synonymy}

According to Newmark, synonymy is defined as a "near TL equivalent to a SL word" (1988, p.84).

\begin{tabular}{|c|c|c|c|}
\hline Number & ST & literal meaning & TT \\
\hline 11 & $\begin{array}{l}\text { My aunt was lading out my } \\
\text { stirabout. }\end{array}$ & $\begin{array}{l}\text { My aunt was lading out my } \\
\text { soup. }\end{array}$ & زن عمويم داشت شورباي مر ا با ملاقه \\
\hline
\end{tabular}

Based on Webster unabridged dictionary, Stirabout is a dish formed of oatmeal boiled in water to a certain consistency and frequently stirred, or of oatmeal and dripping mixed together and stirred about in a pan; a hasty pudding. The best and "near TL equivalent" for this word in Persian which is chosen by translator is شوربا (the name of one kind of pottage). This equivalent in Persian can have the same sense on the reader.

Stirabout is the name of the food and it is related to Newmark's second categorization (material culture).

h. Through-translation

It is "The literal translation of common collocations, name of organizations, the components of compounds and perhaps phrases, which is also known as calque or loan translation" (Newmark. 1988, p.84).

\begin{tabular}{|c|c|c|c|}
\hline Number & ST & literal meaning & TT \\
\hline 12 & $\begin{array}{l}\text { But there he was, sitting up by } \\
\text { himself in the dark in his } \\
\text { confession-box. }\end{array}$ & $\begin{array}{l}\text { He was sitting in the darkness } \\
\text { of the confession chamber. }\end{array}$ & تنها در ناريكى اتاقكى اعتراف نشسته \\
\hline
\end{tabular}

No recognized translation exists for this item. It seems that the translator chooses a word-for-word translation.

\section{i. Shifts or transpositions}

This strategy "involves a change in the grammar from SL to TL". The first type of shift occurs when there is a change from singular to plural. The second type of shift is required when an SL grammatical structure does not exist in the TL. Finally the third type of shift is the one where literal translation is grammatically possible but may not accord 
with the TL (Newmark, 1988, p.86). Of course we should know each of these changes are related to a certain categorization that are described by different translation scholars like Catford (2000, p.141-7) and Vinay and Darbelnet (2000, p.84-93).

Nida (1964, p.237) believes that "a shift may also be necessary when a word that seems to be of the same hierarchical level as the source language word actually occupies a different position because of cultural differences."

\begin{tabular}{|c|c|c|c|}
\hline Number & ST & literal meaning & TT \\
\hline 13 & $\begin{array}{l}\text { He paused at last before the } \\
\text { window of a shop over which } \\
\text { the words refreshment bars } \\
\text { were printed in white letters. }\end{array}$ & $\begin{array}{l}\text { He hesitated in front of the } \\
\text { window of a shop where were } \\
\text { written "refreshment bars" at } \\
\text { the top of it with white color. }\end{array}$ & 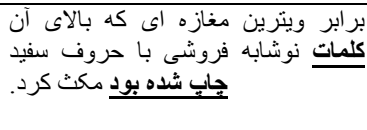 \\
\hline
\end{tabular}

In this sentence we can see the subject in both ST and TT is plural, but the verb is translated in a singular form. In ST both subject and its verb are correspondence but in Persian the subject is singular and its verb is plural. Therefore here we have intra-system shift (Catford, 2000, p.146).

\begin{tabular}{|c|c|c|c|}
\hline Number & ST & literal meaning & TT \\
\hline 14 & $\begin{array}{l}\text { In the Sacred College, you know, } \\
\text { of cardinals and against it ops and } \\
\text { bishops there were two men who } \\
\text { held out against it. }\end{array}$ & $\begin{array}{l}\text { Two men were not agreeing, in } \\
\text { the holy place of cardinals and } \\
\text { bishops. }\end{array}$ & 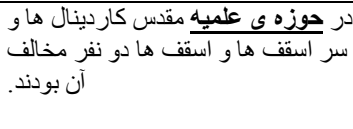 \\
\hline
\end{tabular}

In this sentence college is translated as حوزهى علمبي. In this sentence we have some words which are not familiar for the TT reader. In other words we have a situation in which one aspect of a culture does not exist in another culture. As a result a shift has occurred. In this case we deal with Newmark's fourth type of categorization, because it is related to religion.

\section{j. Modulation}

In this strategy the translators try to create the message of the SL in the TL in conformity with the current norms of the TL. In modulation the SL and the TL may be different in terms of perspective (Newmark, 1988, p.88). Vinay and Darbelnet believe this strategy contains a change in semantic and point of view of the source language (1995, p. 94-9). Based on what they have mentioned, modulation may includes: abstract for concrete, cause for effect, one part for another, reversal of terms, active for passive, space for time, intervals and limits and finally change of symbols (ibid, p.249).

\begin{tabular}{|c|c|c|c|}
\hline Number & ST & literal meaning & TT \\
\hline 15 & $\begin{array}{l}\text {...talking of faints and } \\
\text { worms,... }\end{array}$ & $\begin{array}{l}\text {...taking about malignant } \\
\text { spirits and worms. }\end{array}$ & از ارواح خبيثهو كرم ها حرف مى زد. \\
\hline
\end{tabular}

The meaning of faint based on advanced learner dictionary is "when someone suddenly becomes unconscious". The translator uses the word رواح خبيث؛ (manes) to TT. This is changing in point of view which is a kind of modulation. It means that the translator has changed somehow the view point of the SL writer.

This examples falls into Newmark's fourth categorization; since we deal with concepts.

\begin{tabular}{|c|c|c|c|}
\hline Number & ST & literal meaning & TT \\
\hline 16 & $\begin{array}{l}\text { Somebody'd shoot you for a } \\
\text { coyote if you was by yourself. } \\
\text { ( Steinbeck, of Mice and Men, } \\
\text { p16) }\end{array}$ & $\begin{array}{l}\text { They may hunt you, instead of } \\
\text { a bear, if you were by yourself. }\end{array}$ & اكر تنها باشى ممكن است تو را ركار كنتد. \\
\hline
\end{tabular}

Coyote is a small wolf native to the Western part of North America. The translator replaced coyote by خرس (bear) and in this way changed the semantic and point of view of the SL which is called modulation.

Coyote is a kind of animal so we have fauna which is related to Newmark's first categorization (ecology).

\section{k. Recognized translation}

Newmark (1988, p.89) defined this procedure as "the official generally accepted translation of any institutional term".

\begin{tabular}{|c|c|c|c|}
\hline Number & ST & literal meaning & TT \\
\hline 17 & Farley acts as cavalier & Farley acts as knight. & فارلى نقش شواليه را بر عهده كرفت. \\
\hline
\end{tabular}

The definition of cavalier in Oxford advanced learners is: a supporter of a king in the English Civil War in the 1640s. In Persian translation of this word the translator has chosen the term شو اليه which is "generally accepted" in TT.

\section{l. Compensation}

"This is said to occur when loss of meaning, sound- effect, metaphor or pragmatic effect in one part of a sentence is compensated in another part, or in contiguous sentence" (Newmark, 1988, p.90). Fawcett (1997, pp. 31-33) defines compensation as: "...when something in the source language is not translatable". One example given by Fawcett is the 
problem of translating of some words like tu/vous that are different based on the level of their formality. When they translate into English the only valid equivalent for them is 'you'. For illustrating this method in translation we consider a metaphor that has been occurred in the second hemistich of the second verse of the first ode of Hafiz Divan and English translation by Clarck (youssefi, 2009, 127).

\begin{tabular}{|l|l|l|l|}
\hline Number & ST & literal meaning & TT \\
\hline 18 & $\begin{array}{l}\text { j j } \\
18\end{array}$ & & $\begin{array}{l}\text { From the twist of its musky (dark, } \\
\text { fragrant) curl, what blood (of grief) } \\
\text { befell the hearts (of the lovers of God)! }\end{array}$ \\
\hline
\end{tabular}

As Youssefi has mentioned this translation includes two sets of metaphor, "the perfumed and dark curly hair" and "the dark and twisted path of the spiritual journey toward the true Beloved". In the original text the two concepts are clear- both smell and color of the hair in just one word (مشكينش) - however in its translation, the word musky cannot render it by itself. Therefore in this case loss of meaning is compensated by another part.

\section{m. Paraphrase}

"This is an amplification or explanation of the meaning of a segment of the text" (Newmark, 1988, p. 90). Of course it is notable that Newmark is not completely agree to list paraphrase in translation procedures, "since the word is often used to describe free translation". He explains that "if it is used in the sense of the minimal recasting of an ambitious or obscure sentence, in order to clarify it, I accept it" (ibid, p.91). Adopting Newmark's idea, Kaledaite (2005, pp.32-3) suggested that the difference of this strategy and descriptive equivalent strategy (which is explained in number 5) is that in paraphrase the explanation is much more detailed than that of descriptive equivalent. Furthermore he makes a distinction between paraphrase and functional equivalence (number 4). He said that functional equivalent or neutralization (number4) occurs at the word level, but paraphrase occurs at the higher linguistic level.

Kalèdaite (ibid) talks about the similarities between paraphrasing and functional equivalence or neutralization (number 4) by using Newmark's idea. He believes that paraphrasing is the same as functional equivalent when SL word become neutralized (number 4) or generalized (which is finding a more general word. For example the translator uses كلاه (hat) as an equivalent for bonnet. Bonnet is a kind of hat tied with strings under the chin, formerly worn by women. But because of the lexical gap that existed between source text and TT, the translator has to use the general term كلاه (hat) instead of its exact equivalent. This example is related to clothes which is one of the sub-categorizations of Newmark's second categorization, so it related to material culture).

\begin{tabular}{|c|c|c|c|}
\hline Number & ST & literal meaning & TT \\
\hline 19 & $\begin{array}{l}\text { A yachting cap was shoved far } \\
\text { back from his forehead. }\end{array}$ & $\begin{array}{l}\text { He put the cloth hat of sailing } \\
\text { on the pack of his head. }\end{array}$ & كلاه بِارجه اى قايق رانى را بـ انتهاى \\
\hline
\end{tabular}

Here the word is occurred above word level, the translator paraphrases the item to render the meaning. Since it's related to clothes, it can be classified into Newmark's second categorization (material culture).

n. Couplets, triplet, quadruplet

This strategy occurs when the translator combines two or more than two different procedures for dealing with a single problem (Newmark, 1988, p.91). This strategy is called "combination" by Schaffner and Wiesemann (2001, p.34). Chesterman (1997.p.95) used the term "double presentation" for this strategy.

\begin{tabular}{|c|c|c|c|}
\hline Number & ST & literal meaning & TT \\
\hline 20 & $\begin{array}{l}\text { She was still the leading soprano } \\
\text { in Adam and Eve church. }\end{array}$ & $\begin{array}{l}\text { He was still regarded as the first hand } \\
\text { singer of Superano in the church. }\end{array}$ & 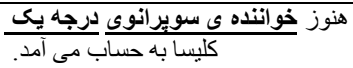 \\
\hline
\end{tabular}

Based on what Newmark said (in number 1) in this sentence we have Transfer strategy because soprano is transfer to the TL without any changing. In the other hand, Adam and Eve is omitted. Instead, the translator has used بك (first string). In Persian translation of this sentence we can see the phrase به حساب مى آمد which isn’t exist in SL. So here we have a combination of different strategies.

Here we deal with Newmark's forth type of categorization (organization, customer, ideas) since we have an activity here.

o. Notes

Notes are "additional information in a translation" (Newmark, 1988, p.91). In This strategy the translator should explain the meaning of the word or phrases in the note. Newmark $(1988$, p.92) mentioned that notes can be within the text, at the bottom of the page, at the end of the chapter and finally as a glossary at the end of the book.

\begin{tabular}{|c|c|c|c|}
\hline Number & ST & literal meaning & $\mathrm{TT}$ \\
\hline 21 & $\begin{array}{l}\text { After a while they went out and } \\
\text { he calls for another punch. }\end{array}$ & $\begin{array}{l}\text { They went out after a while and } \\
\text { he asked for another glass of } \\
\text { beer. }\end{array}$ & 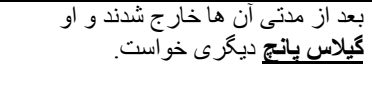 \\
\hline
\end{tabular}

نوشابه ایى است كه از مخلوط كردن شراب يا عرق با آب كرم،شكر و ادويه درست مى كنند. Punch

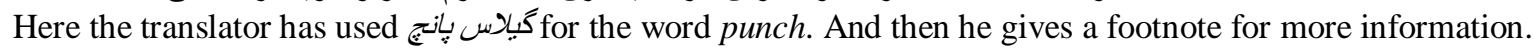


In this sentence we deal with Newmark's Material culture (the second type of his categorization) in the process of translation. Because it is related to food or something we eat.

B. The Cultural Items in "Dubliners"

Based on Newmark's five categorizations and what is discussed above we can extract examples of every cultural item in "Dubliners". The Five categories follow with examples.

\section{Ecology}

Geographical features can be normally distinguished from other cultural terms in that they are usually valuefree...their diffusion depends on the importance of their country of origin as well as their degree of specificity (Newmark, 1988, p.96).

According to Newmark (ibid) geographical features "would normally be transferred, with the addition of a brief culture free third term where necessary in the texts." It was observed that Persian translators in this study use different strategies to translate ecology terms. For example oyster in number 40 is translated as خرجنَ componential analysis strategy.

\section{Material culture}

In the domain of Newmark's second categorization- material culture- in the literary text under this study we deal with three items.

\section{2-1 Clothes}

Based on the fallowing examples, in number 1 tie is translated to ياييون, in number 2 bonnet is translated into كلاه, in number 3 cloak is translated into بالا يوش; therefore, it is clear in some of these examples the translator in this literary text transferred clothes terms by using descriptive equivalents. This is in accordance with Newmark's claims that clothes as a cultural terms may be sufficiently explained for TL general readers (Newmark, 1988, p.97). The translation method depends mainly on the importance of the clothing item in the text, however, "national costumes, when distinctive, are not translated" (ibid).

1. As he stood in the hall giving a last equation to the bows of his dress tie.

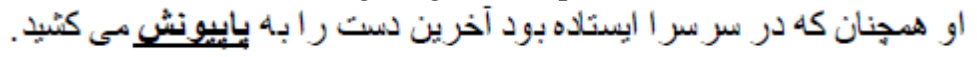

2. The former tenant of our house, a priest, had died in the drawing-room

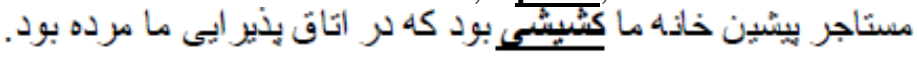

3. Mrs. Kearney wrapped the cloak round her daughter.

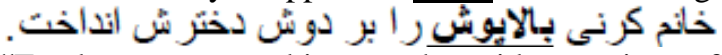

"Food terms are subject to the widest variety of translation procedures" (Newmark,1988, p.96). By looking at number $3,5,6,10,11$, and 21 above, and also by the most cursory look at a menu of a shop we can find that it is enough to reveal how much lexis in this area is internationalized, pizza, vodka, kebab, etc. For proving this idea in this study we have some words like soda, whisky, punch, etc that the translator has used borrowing for translating them. So the translator in this area most of the times has used both borrowing and general words more than other procedures.

1. They drank however it is bohemian.

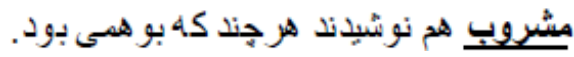

2. A companion dish on which lay a solid rectangle of Smyrna figs, a dish of custard topped with grated nutmeg.

يك ظرف فرنهـ با رويه اي از جوز هندي سدوده آنجا بود.

3. They drink for luck.

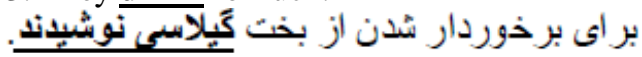

4. Near it on plate lay a very light plum-pudding.

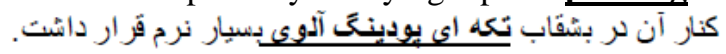

5. One the glass of the window were two flying inscriptions: ginger beer and ginger ale.

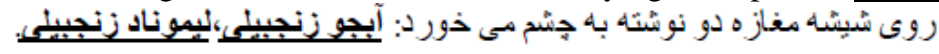

\section{2-2 House}

Newmark (1988, p.97) states "many language communities have a typical house which for general purposes remains untranslated". In this case, the Persian translators use less neutral equivalents and in this way neutralized the original.

\section{Social culture}

In considering social culture one has to distinguish between denotative and connotative problems of translation (Newmark, 1988, p.96). In this case the translator uses different strategies for translating social cultures in the context. Any activity which does a work can be considered in this category. Like 17 to 21 . In number 20 the translator has used

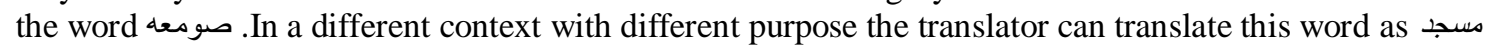

1. They drank however it is bohemian.

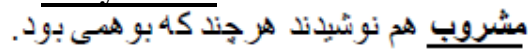

2. A companion dish on which lay a solid rectangle of Smyrna figs, a dish of custard topped with grated nutmeg.

يك ظرف فرنه بارويه اي از جوز هندى سدوده آنجا بود.

3. They drank the health of the queen of hearts and of the queen of diamonds.

بهاه سلامتى بح بي دل و بح بي خشت نوشيدن. 
4. There would be a retreat that week in her convent.

اين هفتّه در صومعف مجلس ذكر و عبادت داريخ.

5. It was his own fault for he frequently mistook his cards.

تقصير خودش بود جون اغلب ورق هايش را عوضى ميكر فت.

4. Organizations, customs, ideas

\section{4-1 Artistic}

In most cases music terms have normally been transferred. For example in number 22 the word waltz is translated as و.number 18, 19 and 20 falls in this case. Because all of them are related to music and music is related to artistic which is one of the sub-categorizations of organization.

1. Villona played a waltz for Farley and rivers.

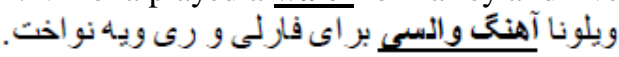

2. The music hall artistes would oblige and Sheridan played waltzes and vamped accompaniments.

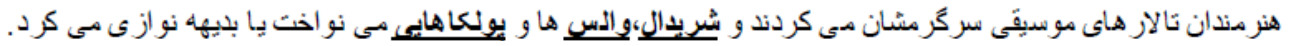

\section{4-2 Religion}

As can be frequently found in literary texts, religious features present cultural implications for translation. In most instances, although Persian translators used various strategies to convey religious words, using general words occurred more than other strategies. We can find the examples of this area and different kinds of strategies for translating religious features in examples 1 to 21 .

1 . There would be a retreat that week in her convent.

آين هفته در صدومعه مجلس دكر و وبادت دار يح.

2. Papal infallibility was the greatest sense in the history of the Church.

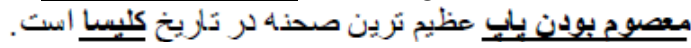

3. He had sent his son to England to be educated in a big catholic college

بسرش را به انكلستان فرستاده بود تا در كالج كاتوليكى بزرى درس بخو اند.

4. We have renewed our baptismal vows.

ييمان هاى مراسم تعميذمان را تكرار كنيم.

5. He attended to his religious duties.

هنوز هم هر هفته تكاليف مذهبي اش را انجام مى داد.

6. Joe had gone to Belfast on a White-Monday trip.

جو در سفرى به مناسبت دوشنبه نزول روح القدس به بلفاست رفته بود.

7. Remembering that the next morning was a mass morning.

با يادآرى اينكه بامداد رز بعد بامداد ريز عشاء ربانى است.

\section{4-3 Politics}

In literary texts the translators use various strategies but they often choose transference. For example in number 41 feudal is transferred in to TL.

1. He emerged from under the feudal arch of the king's Inns.

با اندامى تميز و فروتن از زير رواق فئودالى كينكز اينز بيرون آمد.

5. Gesture and habits

Again we should say that translator may use different strategies and methods in this part. In this study the translator uses functional equivalence which occurred in sentences like the following one.

1. Ignatius Gallaher made a catholic gesture whit his right arm.

ايكناتيوس كالاهر با دست راست به خود صليب كثيد.

\section{CONCLUSION}

Cultures have their own particular ways in perceiving and naming the world and it is the translator's task to consider measures to bring these worlds closer together. There are different strategies which are applied by different translators in translation of culture-specifics items. One of the most important categorizations in this domain is done by Newmark (1988). To arrive at a conclusion about the occurrences of domains found in literary text under study and the strategies applied by translator, a close study was carried out. One literary text and its translation were compared. The results indicated that among different domains such as ecology, material culture, social culture, organizations, gesture and habits, the terms related to the domains of material culture (like food, clothes) and organizations occurred more frequently than those in other domains. The analysis of examples in this research suggests that among all strategies, the translator, in most cases has used general words and borrowing more than other strategies to cope with the lexical gap. Using these strategies is effective in many cases and the translator can make his translation more authentic and tangible in this way. Although in some cases one or more strategies are suggested for each domain, it does not mean that a translator should choose only a certain method or strategy of translation. It is obvious that the translator should choose appropriate strategy based on the situation, purpose and context.

Of course it can also be concluded that in many cases none of these strategies can be applicable and still the translator has many problems for rendering the same meaning and the same effect. The translator may also use other strategies 
like omission, deletion, classifier, etc. which are described by different translation scholars and can be a subject for further studies.

\section{REFERENCES}

[1] Armstrong, N. (2005). Translation, linguistic, Culture: A French- English Handbook. UK: Multilingual Matters Ltd.

[2] Baker, M. (1992). In Other Words: A Coursebook on Translation. London and New York: Routledge.

[3] Catford, J. C (2000). A Linguistic Theory of Translation. London: Oxford university press.

[4] Chesterman A. (1997). Memes of Translation: The Spread of Ideas in Translation Theory. Amsterdam/Philadelphia: J. Benjamins publication company.

[5] Fawcett, P (1997). Translation and Language. UK: St. Jerome, Manchester,

[6] Gambier,Y, Miriam, S, Radegundis, S (2004). Doubts and directions in translation studies. The Netherlands: John Benjamins,

[7] Graedler, A.L. (2000). Cultural shock. Retrieved December 6, 2006 from http://www.hf.uio.no/iba/nettkurs/translation/grammar/top7culture.html

[8] Hervey, S. \& Higgins, I. (2006). German Translation: A Course in Translation Method German to English. London: Routledge.

[9] Hutchins, W. J. and H. L. Somers (1992). An introduction to Machine Translation. London: Academic Press.

[10] Jakobson, R. (1959/2000) "On linguistics aspects and translation", in L. Venuti (ed.) (2000), pp. 113-18.

[11] Joyce, J (1914), Dubliners, New York: Bantam classic

[12] Kalèdaite, V (2005). "Translation of Lithuanian culture specific items into English". From: http://www.minfolit.lt/arch/1/485.pdf. (accessed 29/1/ 2011).

[13] Komissarov, V.N (1991). "Language and Culture in Translation: Competitors or Collaborators?" in traduction, terminologie, redaction. vol. 4. From http://www.erudit.org/revue/ttr/1991/v4/n1/037080ar.pdf

[14] Krings, H.P. (1986). Translation problems and translation strategies of advanced German learners of French. In J. House, \& S. Blum-Kulka (Eds.), Interlingual and intercultural communication (pp. 263-75). Tubingen: Gunter Narr.

[15] Larson, M. (1998). Meaning-based translation: A Guide to cross equivalents. Lanham: University Press of America

[16] Leppihalme, R (1997). Culture bumps: An Empirical Approach to the Translation of Allusions. Britain: Multilingual Matters Ltd.

[17] Loescher, W. (1991). Translation performance, translation process and translation strategies. Tuebingen: Guten Narr.

[18] Miremadi, A. (1993). Theories of translation and interpretation. Tehran: SAMT

[19] Mizani, S. "Cultural Translation”. From: http://www.translationdirectory.com/articles/article1507.php

[20] Munday, J (2001). Introducing Translation Studies: Theories and Applications.USA and Canada: Routledge.

[21] Newmark. (1988). A Textbook of translation. New York: TiceHall Press

[22] Nida, E. (1964). Toward a Science of Translating: With Special Reference to Principles and Procedures Involved in Bible Translating. Netherland: Brill Academic Publishers

[23] Pedersen, J. (2005). How is culture rendered in subtitles? In MuTra Conference Proceedings. Retrieved 7 November 2009 from: http://www.euroconferences.info/.../2005_Pedersen_Jan.pdf

[24] Robinson, D. (1997). Becoming a translator: An Accelerated Course. London and New York: Routledge.

[25] Sandrini, p. (2006). LSP Translation and Globalization. In: Gotti, Maurizio; Šarčević, Susan (eds): Insights into Specialized Translation. Linguistic Insights 46. Bern Berlin Frankfurt: Peter Lang.

[26] Sapir, E. (1929). "The Status of Linguistics as a Science". In E. Sapir (1958): Culture, Language and Personality (ed. D. G. Mandelbaum). Berkeley, CA: University of California Press

[27] Schäffner Ch. And U. Wieseman. (2001). Annotated Texts for Translation: English- German. Functionalist Approaches Illustrated. Britain: Cromwell press Ltd.

[28] Snell-Hornby, Mary. (1988). Translation studies: an integrated approach. Amsterdam: John Benjamins Publishing Company.

[29] Steinbeck, John. (1972). of Mice \& Men. London: Pen Books.

[30] Venuti, L. (2000). The Translation Studies Reader. UK: Routledge.

[31] Vivay, J.P and J. Darbelnet (1958, 2 nd edition 1977). Stylistique compare du francais et de l'anglais: Method de traduction. Paris: Didier, translated and edited by J.C Sager and M.J Hamel (1995) as Comparative stylistics of French and English: a Methodology for Translation. Amsterdam and Philadelphia, PA: John Benjamins.

[32] Wardhaugh, R (2010). An Introduction to sociolinguistics. Oxford: Wiley-Blackwell

[33] Wiersema (2004). Globalisation and Translation. January 2004 from http://translationjournal.net/journal//27liter.htm

[34] Youssefi K.(2009). An Analysis of the Translation of Metaphors in Hafiz's Selected Poem. PHD dissertation. University of Sains Malaysia.

[35] Joys, J, Dubliners, (In Persian): translators: Saleh hoseini and Saffaryan. (1993). Tehran: Niloufar.

[36] Steinbeck, J, Of Mice and Men, (In Persian): translator: Mahdi Khansari, (1990). Tehran: Ashna.

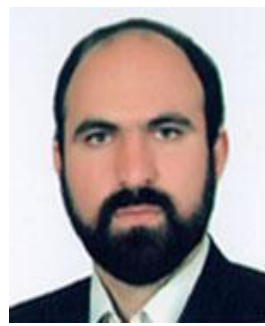

Seyed Mohammad Hosseini Maasoum is an assistant professor of English language and linguistics in Payme Noor University, Iran. He got his first master in TEFL and his second master in Linguistics. He received his $\mathrm{PhD}$ in Linguistics from Ferdowsi University of Mashhad, Iran. In addition to teaching different graduate courses to the students of applied linguistics and translation studies, he is the associate editor of the Journal of Linguistics and Khorasan Dialects published by Ferdowsi University Press. His areas of interest include syntax, psycholinguistics, discourse analysis and translation studies. 


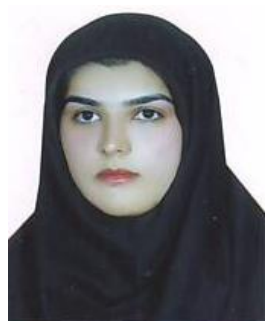

Hoda Davtalab is M.A student of English translation in Azad University of Quchan. She lives in Mashhad and received her B.A in the same major in Imam Reza University of Mashhahd in Iran in 2008. She is an English teacher in some institutes. 